\title{
Transcription Factor Binding Site Mutation
}

National Cancer Institute

\section{Source}

National Cancer Institute. Transcription Factor Binding Site Mutation. NCI Thesaurus.

Code C148652.

A change in the nucleotide sequence of a transcription factor binding site for a gene. 